\section{Space agencies mull over mutual mission to Europa}

Tony Reichhardt, Washington

A future probe to Jupiter's moon Europa and a space-based X-ray observatory should be built as joint ventures between NASA and the European Space Agency (ESA) over the next decade, researchers and agency officials say.

But both agencies will find it a challenge to amass cash for the projects, which will each cost between US\$1 billion and $\$ 2$ billion.

The joint missions were discussed earlier this month at a workshop near Washington that brought together representatives of the world's main space agencies to find where their research agendas overlapped.

Europa exploration and X-ray astronomy emerged as promising areas for cooperation, says Giovanni Bignami, director of the Laboratory of Space Astrophysics (CESR) in Toulouse, France, and chair of ESA's Space Science Advisory Committee.

NASA already has a mission in the design stage that would use a cluster of $\mathrm{X}$-ray satellites to study dark matter and high-energy astronomical sources. ESA and Japan are considering a project with similar goals, called XEUS (for X-Ray Evolving Universe Spectroscopy). The Constellation-X Observatory, as the US mission is called, ranked highly in the most recent decadal review of priorities for US astronomy (see Nature 405,$381 ; 2000)$. XEUS is likely to figure prominently in a similar European plan to be released by Bignami's committee in May. Both missions are planned for launch in about ten years' time, and the two teams have already been collaborating informally in planning scientific objectives, says Harvey Tananbaum of the Harvard-Smithsonian Center for Astrophysics in Cambridge, Massachusetts.

Europa is a high priority for planetary astronomers owing to the liquid ocean thought to lie under its icy crust. US scientists want to keep Europa in NASA's sights following cancellation of the nuclear-powered Jupiter Icy Moons Orbiter (see Nature 433, 342; 2005). ESA has been funding a low-level study of technologies necessary to explore Europa, which could include a small probe sent to its surface. Alessandro Atzei of the agency's ESTEC science centre in the Netherlands says the one-kilogram package originally considered would be too small to have much scientific value. So ESA is looking at slightly bigger surface probes, along with

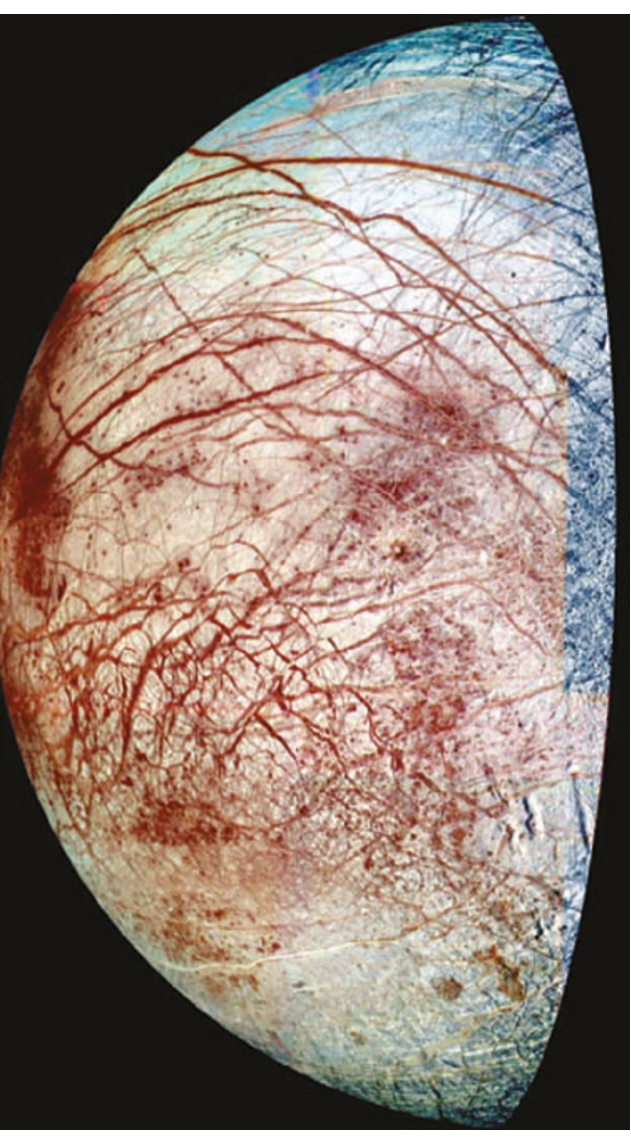

Ice lolly: Europe and the United States must find funds or the mission they are plotting to Jupiter's moon.

an orbiting radar to sound beneath the ice.

Whether a joint US-European mission would carry plutonium-powered batteries, as all previous NASA missions to the outer Solar System have done, is an open question. The joint Cassini mission to Saturn, which is considered a model for future cooperation, used them. ESA's current study is leaving open the possibility of using advanced solar arrays to generate power, as the European agency is not currently able to build plutonium batteries. But it would be natural for NASA to supply them on a joint mission.

All such details await a formal move by the agencies to set up a joint mission study the workshop only got the ball rolling, say Bignami and others. Yet the willingness to cooperate is real, he says. And this time, following Europe's recent success in orbiting Mars and landing on Titan, the two space agencies will be more equal partners than ever before. In the past, says Ron Greeley, a planetary scientist at Arizona State University, Tempe, and long-time supporter of Europa exploration, the more experienced NASA tended to be the senior partner. Now, he says, "the balance has shifted".
Political aide sails into top job at maritime institute

Declan Butler, Paris

A scandal that prompted the resignation of the French finance minister, Hervé Gaymard, last month has ricocheted into the most unlikely of places - the national marine research agency, IFREMER.

Jean-Yves Perrot, who until the scandal broke was Gaymard's political adviser, was nominated by the agency's board on 22 March to take over as the agency's chief executive. Two days later the council of ministers confirmed his appointment.

The move follows a government decision earlier this month not to renew the mandate of the agency's current director-general, Jean-François Minster, a renowned oceanographer.

Perrot is an unknown face in French science. He lost his adviser's job when Gaymard was toppled in a controversy over rents. The French government paid the $€ 14,000$ (US $\$ 18,000$ ) monthly rent on a flat where the minister lived with his family, even though he owned other homes.

Several researchers have expressed outrage at Perrot's appointment, claiming that IFREMER is a victim of the fallout of the Gaymard scandal - especially as Minster's mandate at IFREMER had been viewed positively.

"I am profoundly shocked by the decision," says Pierre Papon, a socialist and former head of both IFREMER and the CNRS, the French national research agency, who is now a physicist at the Industrial Physics and Chemistry Higher Educational Institution in Paris.

IFREMER has traditionally been headed by scientists, whereas Perrot has had a solely political career. He is currently the mayor of Marly-le-Roi, a small town on the outskirts of Paris, and is a local representative in the greater Paris area for Jacques Chirac's ruling, neo-Gaullist UMP party.

"To nominate someone who has neither a scientific attachment, nor scientific or technical competence in the areas of activity of IFREMER, nor knowledge of public research in general, is a serious mistake and a serious political fault," says Papon. Perrot was not available for comment as Nature went to press.

For more news and analysis go to news@nature.com www.nature.com/news 